\title{
Exposure dependent increase in DNA single strand breaks in leucocytes from workers exposed to low concentrations of styrene
}

\author{
S A Solveig Walles, Christer Edling, Helena Anundi, Gunnar Johanson
}

\begin{abstract}
Single strand breaks in DNA were monitored in leucocytes from 17 men occupationally exposed to styrene. Personal air monitoring was carried out during one workday with two diffusion samplers and a portable photoionisation detector placed in the breathing zone. Exposure to styrene was also monitored by analysing styrene in blood and urine and mandelic acid in urine. Single strand breaks were measured in leucocytes by the alkaline elution technique. The biological samples were collected before a shift, at the end of a shift, and the next morning, before the next shift. An exposure dependent increase in single strand breaks was seen at the end of a shift but not before a shift or the next morning. Linear regression analysis indicated that the amount of DNA damage was roughly doubled after eight hours of exposure to $18 \mathrm{ppm}$ styrene or at a urine concentration of $240 \mathrm{mg}$ mandelic acid/g creatinine compared with the damage in non-exposed men. This study indicates that monitoring of single strand breaks with the alkaline elution technique may be a sensitive marker of genotoxic effects. To our knowledge, this is the first time that such a marker has been shown to correlate with exposure to less than $20 \mathrm{ppm}$ styrene.
\end{abstract}

\section{(British fournal of Industrial Medicine 1993;50:570-574)}

Styrene is mainly used for production of plastic polymers. The most extensive occupational exposures to styrene are found in the reinforced plastics

Department of Toxicology, National Institute of Occupational Health, Solna, Sweden

S A S Walles

Department of Occupational Medicine, University Hospital, Uppsala, Sweden

C Edling, $H$ Anundi, G Johanson

Department of Work and Environmental Physiology, National Institute of Occupational Health, Solna, Sweden

G Johanson industry, such as glass fibre hull and tank building. According to the International Agency for Research on Cancer (IARC), there is inadequate evidence of carcinogenicity of styrene in humans and limited evidence for animal carcinogenicity ${ }^{1}$ and styrene is classified by the IARC as a possible human carcinogen, group 2B. The intermediary metabolite of styrene, styrene oxide, was assigned sufficient evidence of carcinogenicity in animals and has thus been classified in group 2A.

After administration of styrene to mice the metabolite styrene oxide was shown to bind covalently to liver DNA. ${ }^{2}$ Styrene has been shown to induce single strand breaks in DNA from peripheral lymphocytes in exposed workers ${ }^{3-5}$ and in various organs of mice. ${ }^{6}$

The aim of the present study was to investigate whether exposure to styrene below $20 \mathrm{ppm}$, the current Swedish permissible exposure concentration, could cause detectable damage to DNA expressed as an increase in single strand breaks in isolated leucocytes from blood. The exposure assessment of individual subjects involved both air and biological monitoring. The study was performed at a small factory with an estimated average exposure to styrene of about $10 \mathrm{ppm}$. In the studies mentioned ${ }^{3-5}$ the alkaline DNA unwinding technique ${ }^{7}$ was used for measuring single strand breaks. In the present study we used the alkaline elution technique, as previous investigations have indicated that this technique is more sensitive to alkylating agents than the alkaline DNA unwinding technique. $^{8}$

Subjects, materials, and methods SUBJECTS

Seventeen of 23 men exposed to styrene in a Swedish plastics factory participated in the study. The men were between 21 and 59 years old and had 0 to 25 years of exposure to styrene. Ten men were smokers at the time of the investigation. Five men smoked 15 to 20 cigarettes a day and the others smoked less. Six men were taking wet snuff and five were taking medicines. One of the men worked four hours a day, the other 16 worked on a full schedule of eight hours a day from Monday to Friday. 


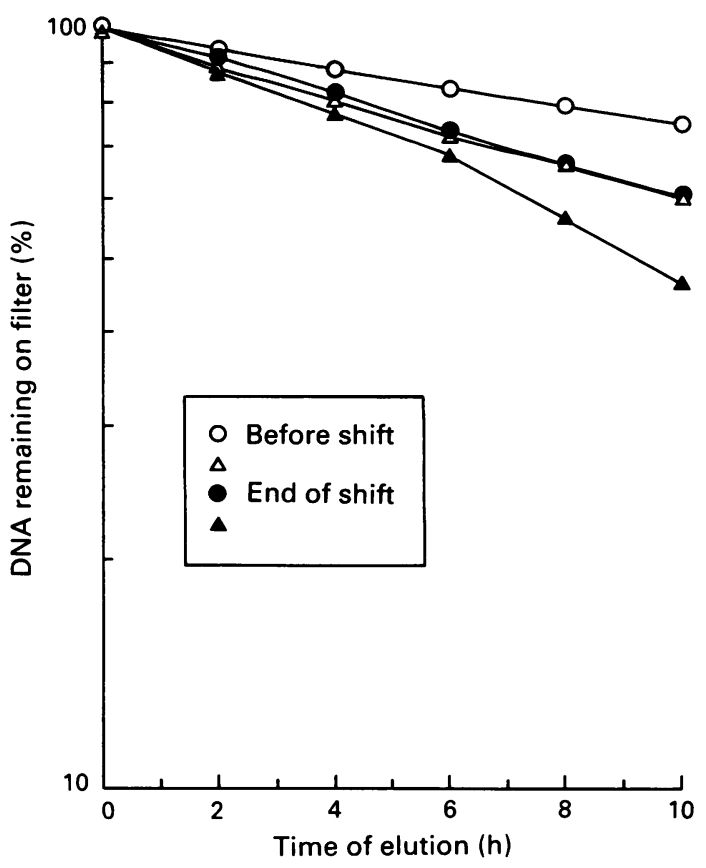

Figure 1 Alkaline elution of DNA from leucocytes of two styrene exposed workers ( $\mathrm{O}$ and $\triangle$.

\section{ASSESSMENT OF EXPOSURE}

Monitoring of exposure was performed on Tuesdays, Wednesdays, and Thursdays for three weeks. The exposure of two new subjects was assessed each day based on random assignment.

Total hydrocarbons were continuously monitored in the breathing zone with mobile photoionisation instruments (MicroTip M-P 100, Photovac Inc, Ontario, Canada) carried by the subjects in small backpacks. The instrument was calibrated daily against a standard preparation of $200 \mathrm{ppm}$ styrene in nitrogen. The measurements were recorded as 15 second averages during the entire workday.

Exposure to solvent vapours was also assessed with active carbon diffusive samplers (Organic Vapor Monitor No 3500, 3M, St Paul, Minnesota, USA). Two samplers were applied in the breathing zone of each subject. Analysis was by gas chromatography (Hewlett Packard 5880A, bentone packed column, nitrogen as carrier gas, flame ionisation detection) after desorption with $2 \mathrm{ml}$ and subsequent dilution 1:10 with carbon disulphide.

Blood and urine samples were collected before and after the workshift and also the following morning before the next shift. The blood samples were collected from the brachial vein into heparinised tubes. The biological samples were rapidly transferred to glass vials that were immediately capped with gas tight teflon lined rubber septa and stored at $-20^{\circ} \mathrm{C}$ until analysis. Sampling was performed in a room adjacent to the factory but with no detectable concentrations of styrene in the air. The biological specimens were thawed and analysed five to nine weeks after sampling. Aliquots of $0.2 \mathrm{ml}$ blood or $2 \mathrm{ml}$ urine were transferred to head space vials for determination of styrene. The vials were allowed to equilibrate at $37^{\circ} \mathrm{C}$ for 20 minutes before analysis by head-space capillary gas chromatography (PerkinElmer 8700, supelcowax 10 capillary column, nitrogen as carrier gas, flame ionisation detection). Mandelic acid and creatinine in urine were analysed by high performance liquid chromatography (Hewlett Packard 1090 LC, spherosorb ODS 2 column). 9

In all chromatographic analyses peaks were identified by comparison of peak retention times. Quantitative determinations were carried out from standard curves prepared from spiked samples.

\section{MEASUREMENT OF SINGLE STRAND BREAKS}

Venous blood samples were collected in tubes containing EDTA in the morning before and in the afternoon after the workshift. Samples were also collected next morning. All samples were stored at $-18^{\circ} \mathrm{C}$ until analysed three to four months later. It has been shown that storage of blood samples for at least six months at $-18^{\circ} \mathrm{C}$ does not influence the level of single strand breaks. After thawing, the blood was diluted four times with $0.9 \% \mathrm{NH}_{4} \mathrm{Cl}$ and the leucocytes were collected by centrifugation at $215 \mathrm{~g}$ for 10 minutes. The pellet was washed once with phosphate buffered saline (PBS). The alkaline elution technique was used to determine the level of single strand breaks in the DNA from the leucocytes. The method was as described by Kohn et al ${ }^{10}$ with minor mofications. ${ }^{11}$ Briefly, $7 \times 10^{5}$ cells were loaded on to polyvinyl chloride filters with $2 \mu \mathrm{m}$ pores, lysed with sarcosyl EDTA solution (2\% sarcosyl in $0.02 \mathrm{M}$ EDTA, $\mathrm{pH} 9.5$ ), and washed with $0.02 \mathrm{M}$ EDTA (pH 9.5). Single stranded DNA was eluted from the filters for 10 hours with $0.02 \mathrm{M}$ EDTA adjusted to $\mathrm{pH} 12 \cdot 1$ with tetraethylammonium hydroxide at a flow rate of $0.03 \mathrm{ml} /$ minute. The DNA remaining on the filters was removed by heating at $80^{\circ} \mathrm{C}$ for $30 \mathrm{~min}$ utes, followed by vigorous shaking for one hour. All samples were adjusted to $\mathrm{pH} 7.0$ with $0.25 \mathrm{M}$ $\mathrm{KH}_{2} \mathrm{PO}_{4}$. The amount of DNA was determined by fluorometry after additon of the fluorochrome Hoechst 33258. ${ }^{12}$ Figure 1 shows typical DNA elution curves. The DNA damage was calculated as the normalised area above the elution curve (NAAC) according to Brunborg et al. ${ }^{13}$ 
Relation between $S S B^{*}$ and selected expressions of exposure to styrene and smoking in occupationally exposed workers, as calculated by linear regression analysis.

\begin{tabular}{|c|c|c|c|c|}
\hline $\begin{array}{l}\text { Independent } \\
\text { variable }(s)\end{array}$ & $\begin{array}{l}\text { No of } \\
\text { observations }\end{array}$ & Intercept & Slope $(95 \%$ CI) & $\begin{array}{l}\text { Correlation } \\
\text { coefficient }\end{array}$ \\
\hline \multicolumn{5}{|c|}{ Smokers } \\
\hline $\begin{array}{l}\text { Styrene† } \\
\text { Mandelic acid } \neq\end{array}$ & $\begin{array}{r}9 \\
10\end{array}$ & $\begin{array}{l}36 \cdot 7 \\
35 \cdot 7\end{array}$ & $\begin{array}{l}1.71(0.18 \text { to } 3.24) \\
0.116(0.012 \text { to } 0.221)\end{array}$ & $\begin{array}{l}0.71 \\
0.67\end{array}$ \\
\hline $\begin{array}{l}\text { Styrenet } \\
\text { Mandelic acid } \neq\end{array}$ & $\begin{array}{l}7 \\
7\end{array}$ & $\begin{array}{ll}29.0 & N \\
29 \cdot 2 & \end{array}$ & $\begin{array}{l}1.1(0.061 \text { to } 2 \cdot 15) \\
0.145(-0.002 \text { to } 0.292)\end{array}$ & $\begin{array}{l}0.77 \\
0.75\end{array}$ \\
\hline $\begin{array}{l}\text { Styrene† } \\
\text { Mandelic acid } \ddagger \\
\text { Cigarettes per day } \\
\text { Styrenet } \\
+ \text { cigarettes per day } \\
\text { Mandelic acid } \\
+ \text { cigarettes per day }\end{array}$ & $\begin{array}{r}16 \\
17 \\
7 \\
16\end{array}$ & $\begin{array}{l}\text { Smokers } \\
31.9 \\
32.2 \\
32.9 \\
25.9\end{array}$ & $\begin{array}{l}1.8(0.81 \text { to } 2.79) \\
0.132(0.067 \text { to } 0.198) \\
0.955(0.16 \text { to } 1.75) \\
1.55(0.78 \text { to } 2.32) \\
0.89(0.33 \text { to } 1.45) \\
0.113(0.051 \text { to } 0.175) \\
0.615(0.01 \text { to } 1.22)\end{array}$ & $\begin{array}{l}0.72 \\
0.74 \\
0.55 \\
0.86\end{array}$ \\
\hline
\end{tabular}

*DNA single strand breaks in leucocytes collected at the end of a shift (NAAC $\left.\times 10^{-3} \mathrm{~h}^{-1}\right)$.

†Styrene in breathing zone; whole day time weighted average measured by passive dosimetry (ppm).

$¥ M$ andelic acid in urine at the end of a shift ( $\mathrm{mg} / \mathrm{g}$ creatinine).

\section{STATISTICAL TREATMENT}

Paired $t$ tests, single and multiple linear regression analysis, and the Spearman rank correlation test were used to investigate the relation of single strand breaks to different measures of exposure to styrene, age, smoking habits, etc. Statistical calculations were carried out with Statview II on a Macintosh computer. The level of significance was set at $<0.05$.

\section{Results}

The exposure to styrene as measured by passive dosimetry gave eight hour time weighted average (TWA) concentrations of styrene in the breathing zone of between 0.04 and $20 \mathrm{ppm}$ (arithmetic mean $7.0 \mathrm{ppm}, \mathrm{n}=16$ ). (A higher styrene concentration of $32 \mathrm{ppm}$ was registered in one man who used respiratory protection for the whole day. This subject was not included in the statistical comparisons based on air measurements.) As well as styrene, $0.2-21 \mathrm{ppm}$ acetone and $0.01-2 \mathrm{ppm}$ toluene were found in the air. The excretion of mandelic acid in urine varied from below the detection limit to $261 \mathrm{mg} / \mathrm{g}$ creatinine (arithmetic mean $70 \mathrm{mg} / \mathrm{g}, \mathrm{n}=17$ ) at the end of the shift.

The single strand breaks average increased from NAAC $33 \times 10^{-3} \mathrm{~h}^{-1}$ before a shift to $41 \times 10^{-3} \mathrm{~h}^{-1}$ at the end of a shift $(p=0.03$ in paired $t$ test, $\mathrm{n}=16$; one sample collected before the shift was lost). Linear regression analysis showed statistically significant exposure dependent relations between single strand breaks at the end of a shift and all measurements of biological exposure: styrene in blood, styrene in urine, and mandelic acid in urine before and after correction for creatinine. Also, exposure dependent relations were obtained for almost all measurements of styrene in the breathing zone: whole day TWA (table), last four hour TWA, duration of exposures above $50 \mathrm{ppm}$, and maximum styrene concentration. Similar relations were obtained when single strand breaks at the end of a shift was replaced by the increase in single strand breaks during a shift. The most recent exposure to styrene-that is, the TWA of styrene in air during the last 30 minutes to two hours before blood sampling, did not correlate significantly with single strand breaks at the end of a shift. The table and fig 2 show the exposure-effect relations for the most important exposure variables.

No significant correlation was seen between any measure of exposure to styrene and single strand breaks before a shift or single strand breaks the next

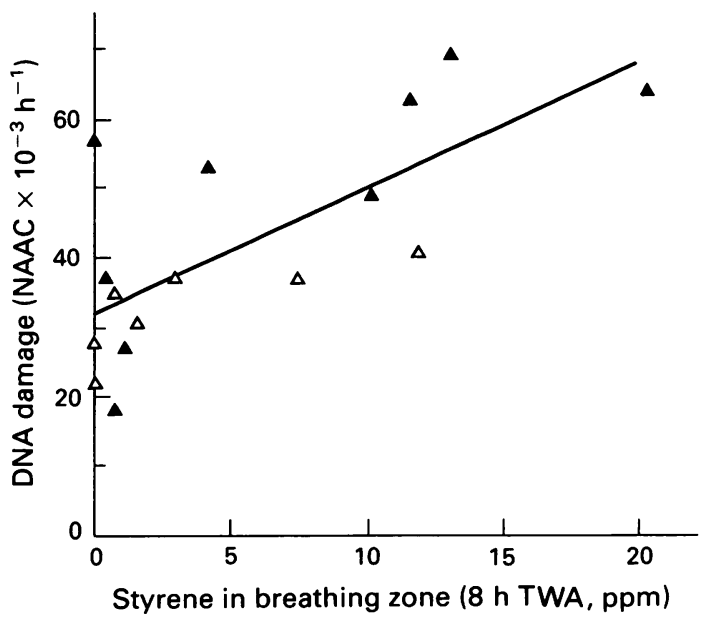

Figure 2 Relation between exposure to styrene, expressed as whole day time weighted average concentration of styrene in the breathing zone, and DNA damage in leucocytes collected at the end of a shift. Open and filled symbols refer to nonsmokers and smokers respectively. 


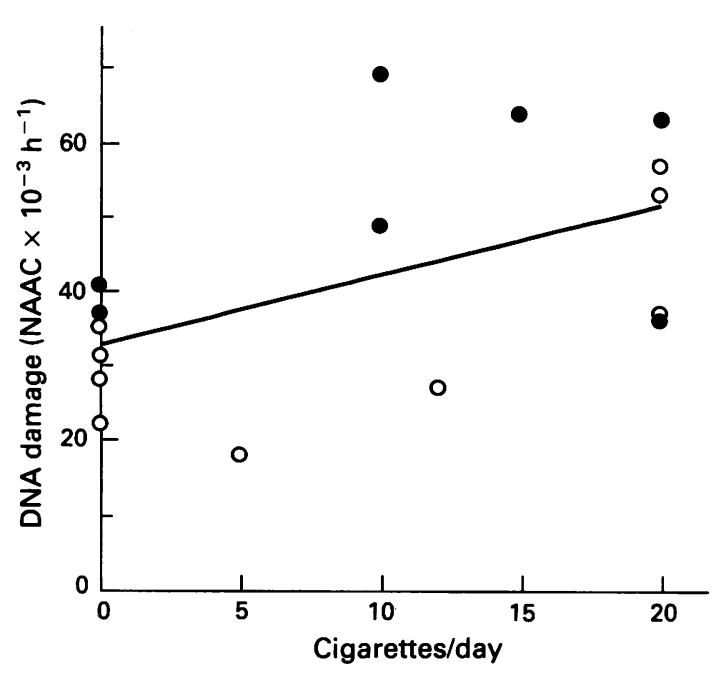

Figure 3 Relation between smoking habits and DNA damage in leucocytes collected at the end of a shift. The subjects were dichotomised into low (< 5 ppm, open symbols) and high (> 5 ppm, filled symbols) exposure groups. The limit of 5 ppm was arbitrarily set.

morning. Also, there was no correlation between single strand breaks and age, years of present employment, years of exposure to styrene, or use of wet snuff.

Smoking significantly influenced the increase in single strand breaks during a shift $(p=0.0093$, Spearman rank correlation; see also table and figs 2 and 3). There were no significant differences between smokers and non-smokers with respect to single strand breaks before a shift or next morning. The smoking habits seemed to be evenly distributed in the group as no significant correlation was seen with any measure of exposure to styrene.

From the multiple linear regression analyses (table) it can be calculated that the single strand breaks at the end of a shift were doubled after an eight hour exposure to about $18 \mathrm{ppm}$ styrene. With a biological measure of exposure, single strand breaks at the end of a shift were doubled at a concentration of mandelic acid in urine of about $240 \mathrm{mg} / \mathrm{g}$ creatinine. Smoking 20 cigarettes a day increased the amount of single strand breaks at the end of a shift by about $50 \%$.

Four of the five men taking medicines showed no tendencies towards increased single strand breaks. In one man treated with paracetamol, however, single strand breaks rose from NAAC $37 \times 10^{-3} \mathrm{~h}^{-1}$ before a shift to $69 \times 10^{-3} \mathrm{~h}^{-1}$ at the end of a shift (figs 2 and 3). This was the highest value found in the group.

One man with low exposure to styrene (whole day TWA $0.05 \mathrm{ppm}$ ) had a strikingly high value for single strand breaks (NAAC $57 \times 10^{-3} \mathrm{~h}^{-1}$ ) at the end of a shift (figs 2 and 3 ). This man, who smoked 20 cigarettes a day, also had a high value (NAAC $50 \times 10^{-3} \mathrm{~h}^{-1}$ ) before a shift.

\section{Discussion}

In our present investigation we found a good correlation between individually monitored exposure to styrene and DNA damage expressed as single strand breaks. Linear regression analysis indicated that single strand breaks were doubled after eight hours of exposure to $18 \mathrm{ppm}$ styrene.

Further, our study indicates that smoking may result in an increase in single strand breaks. A nonsignificant tendency to a decrease in single strand breaks with years of employment and exposure to styrene may have been indirectly related to smoking habits, or vice versa, as smoking tended to decrease with age (data not shown). In another investigation (unpublished) we found no effect on the level of single strand breaks in a group of smokers who had smoked three to nine cigarettes a day.

It is noteworthy that the man in our study with the highest single strand break level at the end of a shift had taken paracetamol. Hongslo et al have shown increased single strand breaks in tissues from mice treated with this drug. ${ }^{16}$ Hence, intake of paracetamol might be another confounding factor in monitoring of single strand breaks.

Contradictory results have been obtained with regard to possible genotoxic effects of styrene in occupationally exposed people. In several studies, increases in the number of chromosomal aberrations, sister chromatid exchanges and micronuclei in peripheral lymphocytes have been found in workers exposed to styrene. Other studies have been negative. In most of the studies with positive findings, the exposure was at least $25 \mathrm{ppm}$. In a recent review, Barale et al concluded that styrene induced chromosomal aberrations have a threshold limit of $50 \mathrm{ppm}$ and that it is not possible to estimate any threshold limits for sister chromatid exchanges, micronuclei, and single strand breaks, due to limited data. ${ }^{14}$ Sorsa and colleagues found no effects of exposure to styrene $(5-185 \mathrm{ppm}$ in laminators, 1-133 ppm in other workers) on chromosomal aberrations, sister chromatid exchanges, or micronuclei in peripheral blood lymphocytes. ${ }^{15}$

In a recent study, however, Brenner et $\mathrm{al}^{4}$ found a significant increase of about $50-100 \%$ in the number of micronuclei, single strand breaks, and $\mathrm{N}$-acetoxy-2-acetylaminofluorene induced DNA binding in workers exposed to $1-44 \mathrm{ppm}$ (arithmetic mean $17 \mathrm{ppm}$ ) styrene.

Our results suggest that most of the DNA damage in the leucocytes will be repaired by the next day. The time profile of DNA damage may, however, depend on the tissue kinetics of styrene and 
styrene oxide, as well as the capacity of the DNA to repair in various cell types. The damage may therefore persist for a longer time in other cell types and tissues than in leucocytes. In mice intraperitoneally dosed with styrene $(5-10 \mathrm{mg} / \mathrm{kg}$ ) the levels of single strand breaks in lung and brain tissues were higher at 24 hours than at four hours after administration. ${ }^{6}$

In conclusion, our study indicates that monitoring of single strand breaks with the alkaline elution technique in combination with simultaneous individual exposure monitoring may be a sensitive marker of genotoxic effects.

Requests for reprints to: Dr S A S Walles, Department of Toxicology, National Institute of Occupational Health, S-171 84 Solna, Sweden.

1 International Agency for Research on Cancer. IARC Monographs on the evaluation of the carcinogenic risks to humans, supplement 7 , overall evaluation of carcinogenicity: an updating of IARC monographs from volumes 1-42. Lyon: IARC, 1987:345-7.

2 Byfält Nordqvist $M$, Löf A, Osterman-Golkar S, Walles SAS. Covalent binding of styrene and styrene-7,8-oxide to plasma proteins, hemoglobin and DNA in the mouse. Chem Biol Interact 1985;55:63-73.

3 Mäki-Paakkanen J, Walles SAS, Osterman-Golkar S, Norppa H. Single-strand breaks, chromosome aberrations, sisterchromatid exchanges, and micronuclei in blood lymphocytes of workers exposed to styrene during the production of reinforced plastics. Environ Mol Mutagen 1991;17:27-31.

4 Brenner DD, Jeffrey AM, Latriano $\mathrm{L}$, et al. Biomarkers in styrene-exposed boatbuilders. Mutat Res 1991;261:225-36.
5 Walles SAS, Norppa H, Osterman-Golkar S, Mäki-Paakkanen J. Single-strand breaks in DNA of peripheral lymphocytes of styrene-exposed workers. In: Bartsch $\mathrm{H}$, Hemminki $\mathrm{K}$, $\mathrm{O}^{\prime}$ Neill $\mathrm{K}$, eds. Methods for detecting $D N A$ damaging agents in humans, Lyon: IARC, 1988:223-6.

6 Walles SAS, Orsén I. Single-strand breaks in DNA of various organs of mice induced by styrene and styrene oxide. Cancer Lett 1983;21:9-15.

7 Ahnström G, Erixon K. Radiation induced strand breakage in DNA from mammalian cells. Strand separation in alkaline solution. Int f Radiat Biol 1973;23:285-9.

8 Walles SAS, Ringborg U. Induction and time course of DNA single-strand breaks in lymphocytes from patients treated with decarbazine. Carcinogenesis 1991;12:1153-4.

9 Ogata M, Taguchi T. Simultaneous determination of urinary creatinine and metabolites of toluene, xylene, styrene ethylbenzene and phenol by high performance liquid chromatography. Int Arch Occup Environ Health 1988;61:131-40.

10 Kohn KW, Erickson LC, Ewig RAG, Friedman CA Fractionation of DNA from mammalian cells by alkaline elution. Biochemistry 1976;15:4629-37.

11 Walles SAS. Mechanisms of DNA damage induced in rat hepatocytes by quinones. Cancer Lett 1992;63:47-52.

12 Cesarone CF, Bolognesi C, Santi L. Improved microfluorometric DNA determination in biological material using 33258 Hoechst. Anal Biochem 1979;100:188-97.

13 Brunborg G, Holme J, Söderlund E, Dybing E. Organ-specific genotoxic effects of chemicals: the use of alkaline elution to detect DNA damage in various organs of in vivo-exposed animals. In: Mendehlson ML, Albertini RJ, eds. Mutation and the environment. Part D: carcinogenesis. New York: WileyLiss, 1990:43-52.

14 Barale R. The genetic toxicology of styrene oxide. Mutat Res 1991;257:107-26.

15 Sorsa $M$, Anttila A, Järventaus $H$, et al. Styrene revisitedexposure assessment and risk estimation in reinforced plastics industry. Prog Clin Biol Res 1991;372:187-95.

16 Hongslo JK, Brunborg G, Søderlund EJ, Holme JA Paracetamol induces DNA single strand breaks and inhibits DNA repair and replicative DNA synthesis in rodents. Pharmacol Toxicol 1992;70:30.

Accepted 27 July 1992 